\title{
Canine visceral leishmaniasis in Londrina, Paraná - investigation and case report
}

\section{Leishmaniose visceral canina em Londrina, Paraná - investigação e relato de caso}

\author{
Eloiza Teles Caldart ${ }^{1 *}$; Cínthia Peres Camilo²; Jéssica Regina Moreira ${ }^{2}$; Andressa \\ Maria Rorato Nascimento De Matos $^{3}$; Fernanda Pinto Ferreira ${ }^{1}$; Aline Ticiani \\ Pereira Paschoal ${ }^{3}$; Weslem Garcia Suhett ${ }^{4}$; Odilon Vidotto5; Regina Mitsuka- \\ Breganó $^{5}$; Italmar Teodorico Navarro ${ }^{5}$
}

\begin{abstract}
Dogs are considered the main reservoirs of visceral leishmaniasis for humans, which also present a chronic and severe clinical picture when affected. The objective of the present report was to describe a canine visceral leishmaniasis case diagnosed in Londrina, an indene city, and its investigation. A street animal with extensive dermatological lesions, onychogryphosis, mild anemia and leukopenia was attended at a veterinary hospital in Londrina, where positivity was reported for Leishmania spp. in serological tests. Cytology was positive in bone marrow, PCR and parasite culture were positive in skin, spleen, liver, lymph node and bone marrow, and DNA sequencing confirmed the species of the parasite as $L$. (L.) infantum. The official diagnosis was made by the Central Laboratory of Paraná (LACEN), and through an official report, an investigation of the case was started for the confirmation of autochthony. An active search for the vector and other canine cases in the neighborhood was carried out along with a search for information on the origin of the animal in question. However, the species, Lutzomyia longipalpis, new canine cases, or origin of the sick animal were not identified. Although, the present case cannot be confirmed as autochthonous, we suggest that it is necessary to disseminate the present report to serve as a warning to veterinarians and other public health professionals in the northern region of Paraná to be attentive to suspicious cases and to not fail to investigate these cases to the end. Key words: Leishmania (L.) infantum. Lutzomyia longipalpis. Street dog.
\end{abstract}

\section{Resumo}

Os cães são considerados os principais reservatórios da leishmaniose visceral para os humanos e também apresentam quadro clínico crônico e grave quando acometidos. O objetivo do presente relato foi descrever um caso de leishmaniose visceral canina diagnosticado em Londrina, um cidade indene,

1 Discentes de Doutorado, Departamento de Medicina Veterinária Preventiva, Universidade Estadual de Londrina, UEL, Londrina, PR, Brasil. E-mail: eloiza.vet@gmail.com; nandaferreiravet@gmail.com

2 Discentes da Residência, Departamento de Clínicas Veterinárias, UEL, Londrina, PR, Brasil. E-mail: cinthiaperes@hotmail.com; jessicajrm@gmail.com

3 Discentes de Mestrado, Departamento de Medicina Veterinária Preventiva, UEL, Londrina, PR, Brasil. E-mail: andressarorato@ gmail.com; ticianipaschoal@gmail.com

4 Prof. Dr., Departamento de Clínicas Veterinárias, UEL, Londrina, PR, Brasil. E-mail: weslemsuhett@gmail.com

5 Profs. Drs., Departamento de Medicina Veterinária Preventiva, UEL, Londrina, PR, Brasil. E-mail: vidotto@uel.br; rbregano@ uel.br; italmar@uel.br

* Author for correspondence 
e sua investigação. Um animal de rua com extensas lesões dermatológicas, onicogrifose, anemia leve e leucopenia foi atendida em um hospital veterinário em Londrina, onde a positividade foi relatada para Leishmania spp. em testes sorológicos. A citologia foi positiva na medula óssea, a PCR e a cultura parasitária foram positivas na pele, baço, fígado, linfonodo e medula óssea. Com o sequenciamento de DNA confirmamos as espécies do parasita como $L$. (L.) infantum. O diagnóstico oficial foi feito pelo Laboratório Central do Paraná (LACEN) e, através de um relatório oficial, iniciou-se a investigação do caso para a verificação de autoctonia. Foi realizada uma busca ativa do vetor e outros casos caninos suspeitos no bairro, bem como a procura de informações sobre a origem do animal doente. No entanto, a espécie Lutzomyia longipalpis não foi identificada, nem novos casos caninos foram identificados ou mesmo a origem do animal doente esclarecida. Embora o presente caso não possa ser confirmado como autóctone, sugerimos que seja necessário divulgar o presente relato para servir de aviso aos veterinários e outros profissionais de saúde pública na região norte do Paraná para estarem atentos a casos suspeitos e não deixar de investigar esses casos até o fim.

Palavras-chave: Leishmania (L.) infantum. Lutzomyia longipalpis. Cão errante.

\section{Introduction}

The main etiologic agent of human and canine visceral leishmaniasis (VL) in Brazil is Leishmania (Leishmania) infantum, and its vectors are Lutzomyia longipalpis and Lutzomyia cruzi; the latter has been incriminated as a vector so far only in Mato Grosso do Sul state (SANTOS et al., 1998). Approximately 58,000 new human cases of VL are reported annually in the world; Brazil annually reports an average of 3,481 cases with an average mortality rate of $7.2 \%$ (ALVAR et al., 2012). The transmission conditions of leishmaniasis are continually changing in relation to environmental, demographic and human behavioral factors that lead to changes in the geographical reach and density of vectors and reservoirs, which increase human and animal exposure to infected sandflies (CALDART et al., 2017).

What has occurred in the southern region of Brazil in recent years is proof of the frank geographical expansion of this disease. The vector was first identified in 2009 in Rio Grande do Sul (BRASIL, 2010), a state that represents 19 confirmed human cases. Santa Catarina had the first canine case reported in 2011 and the first human case reported in August 2017 (WENZEI, 2017); thus far, the vector has not been found in this state. In the state of Paraná, the vector was first described in 2012 in Foz do Iguaçu (SANTOS et al., 2012), the southwest region of the state (500 $\mathrm{km}$ from Londrina), and in 2013, autochthonous canine cases had already shown faster agent expansion (BISETTO-JUNIOR et al., 2014), and the first human case was reported in 2015. Despite the efforts of the municipal and state health agencies, it was not possible to contain the vector propagation and agent dispersion between dogs and humans, leading to two deaths in just two years in Foz do Iguaçu. It has been reported that the vector has already advanced approximately $60 \mathrm{~km}$, having been found in the municipality of Medianeira (verbal communication). Allochthonous canine cases are frequently diagnosed in municipalities, such as Curitiba and Londrina (THOMAZSOCCOL et al., 2009). Taking into account that dogs are the main reservoir of this disease for humans, the intense risk to the state is clear and depends on whether the geographical expansion of the vector to this important zoonosis is stalled.

Visceral canine leishmaniasis is spreading rapidly from cities in the western part of São Paulo state (Presidente Prudente, $167 \mathrm{~km}$ from Londrina), which is the most feasible route to be traveled by the disease (parasite and vector) toward the northern border of the Paraná state (D'ANDREA et al., 2015); these two states are separated by the Paranapanema River. The objective of the present report was to describe a canine visceral leishmaniasis case diagnosed in Londrina and its investigation. 


\section{Materials and Methods}

In January 2017, a female canine of undetermined breed, of approximately seven to twelve months of age, was attended after being found on the street. An anamnesis and physical examination were done, blood and serum were collected for hemogram and for indirect immunofluorescence reaction (IFAT) (OLIVEIRA et al., 2009) and an enzyme immunoassay (ELISA) (SZARGIKI et al., 2009) for the detection of anti-Leishmania spp. antibodies was performed. A serum sample was sent to the Central Laboratory of the State of Paraná (LACEN), where a series of official tests (ELISA and rapid test) were performed.

After clinical and laboratory diagnosis of canine visceral leishmaniasis (CVL), euthanasia was recommended, since the animal had no responsible person and carried a severe zoonosis at an advanced stage, posing a risk to public health. A necropsy of the animal was performed, as well as bone marrow puncture for cytology and the collection of organ fragments for PCR of the ITS1 gene (SCHÖNIAN et al., 2003) and parasite culture. The parasite culture was performed in diphase medium Blood Agar Base (BAB) and Schneider.

The investigation of the case was carried out together with the Health Surveillance Unit of the Municipality and with the 17th Regional of Health of the State of Paraná to verify the autochthony of the same. Falcon automatic light traps were placed where the animal was found $\left(-23.324970^{\circ}\right.$; $-51.185379^{\circ}$ ), for three consecutive days from $6: 00$ p.m. to 6:00 a.m., for the collection of sandflies in the month of March, which is suitable for this type of collection because it still presents high temperature and humidity. Municipal agents of endemics made an active search from house to house for new cases in the neighborhoods where the sick dog was found and took photos of the sick animal with the objective of identifying a possible owner.

This study was approved by the Ethics and Animal Experimentation Committee of Londrina State University (UEL) and was approved $\left(\mathrm{n}^{\circ} 124 / 16\right)$ for execution.

\section{Results and Discussion}

The animal presented claudication in the right anterior limb with the absence of proprioception, increased volume and angular deviation of the carpo-radio-ulnar joint, extensive lesions of the skin, with alopecia, epidermal collars, crusting, scaling, hyperpigmentation, hyperkeratosis and onychogryphosis. In the radiographic examination, an ulna fracture was identified with bad union and osteopenia. The hemogram showed mild anemia with hematocrit of $32 \%$ and leukopenia of 4200 .

Regarding the serological tests, the animal had a titer of 320 to IFAT and positivity to the ELISA. In cytology, promastigote forms were observed inside and outside the cytoplasm in bone marrow macrophages (Figure 1). The PCR and parasite culture were positive in skin, spleen, liver, lymph node and bone marrow samples. The parasite species, L. (L.) infantum, was confirmed after DNA sequencing of the ITS1 gene. At necropsy, abdominal fluid and increased splenic white pulp were observed. The tests carried out at LACEN, and both ELISA and the rapid test were positive, leading to the official confirmation of the case and triggering of its investigation. 
Figure 1. Presence of amastigote forms compatible with Leishmania spp. inside and outside the cytoplasm of macrophages.

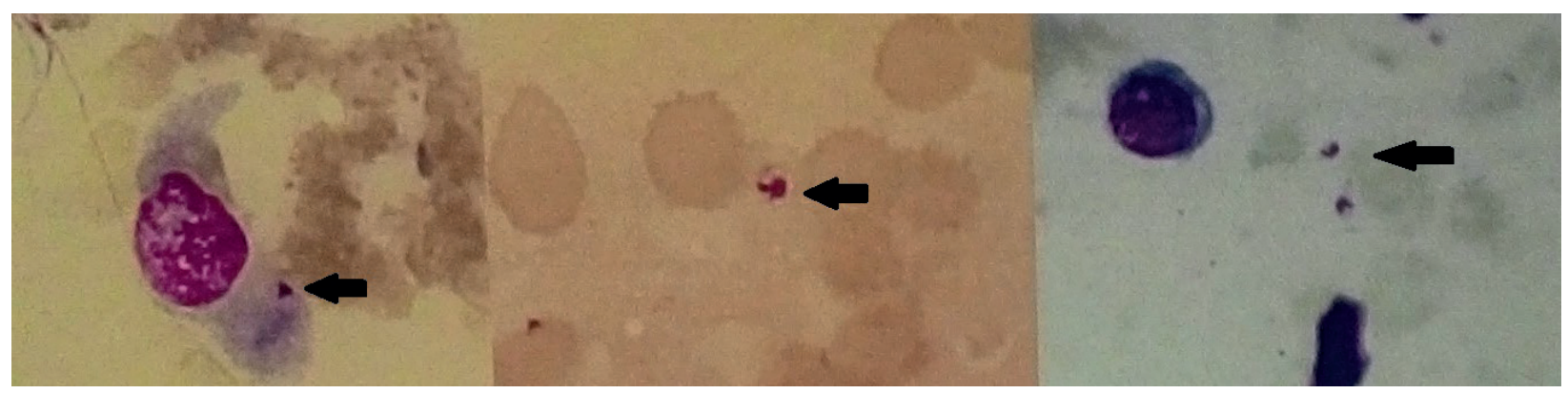

The active search from house to house could neither find any new suspected cases in the neighborhood nor obtain information about the origin of the sick animal. L. longipalpis was not captured in any of the traps for sandfly collections, although the search was made during the period of great circulation of the vectors. Thus, the investigation was inconclusive, not allowing for the notification of this case as the first autochthonous case in the municipality of Londrina.

Because the place where the animal was found is close to a highway, we can suggest that it may even have come, for example, from São Paulo. The animal's age makes us think that it may have acquired the disease through transplacental transmission.

According to reports from residents and watchmen, the place where the animal was found, a valley bottom, is a place where animals are abandoned, which makes the investigation more complex, since the animal possibly did not acquire the disease in that neighborhood. The absence of vectors does not exclude the possibility of local infection. Santa Catarina state has notified of CVL cases since 2011, and so far, the vector has not been identified in the state (WENZEI, 2017). In Rio Grande do Sul state, the vector was identified one year after the notification of the first CVL case (BRASIL, 2010).

A study published in 2017, concerned with synanthropic rodents from the municipality of Londrina, reported a specimen of the species Rattus rattus harboring the protozoan L.(L.) infantum in blood (CALDART et al., 2017). Although the present case cannot be confirmed, as autochthonous together with the discovery in the roof rat, we suggest that it is necessary to disseminate the present report to serve as a warning to veterinarians and other public health professionals in the northern region of Paraná to be attentive to suspicious cases and to not fail to investigate these cases to the end.

\section{Conclusion}

The diagnosis of canine visceral leishmaniasis in the present case was based on evident clinical signs, physical examination, complementary exams and an official LACEN report. Although the present case cannot be confirmed as autochthonous, we suggest that it is necessary to disseminate the present report to serve as a warning to veterinarians and other public health professionals in the northern region of Paraná to be attentive to suspicious cases and to not fail to investigate these cases to the end.

\section{Acknowledgements}

The authors are grateful to the teams of Environmental Surveillance of the municipality of Londrina and of the 17th Regional of Health of the Paraná state. The authors also thank Dr. Giovana Wingeter di Santis for the interpretation of cytology slides. 


\section{References}

ALVAR, J.; VELEZ, I. D.; BERN, C.; HERRERO, M.; DESJEUX, P.; CANO, J.; JANNIN, J.; BOER, M. den; The WHO Leishmaniasis Control Team. Leishmaniasis worldwide and global estimates of its incidence. PLoS ONE, San Francisco, v. 7, n. 5, p. e35671, 2012.

BISETTO-JUNIOR， A.; THOMAZ-SOCCOL， V.; NAVARRO, I. T. Leishmaniose visceral no Estado do Paraná. Revista do Conselho Regional de Medicina Veterinária do Paraná, Curitiba, v. 41, n. 1, p. 6-7, 2014.

BRASIL. Ministério da Saúde. Secretaria de Vigilância em Saúde. Departamento de Vigilância Epidemiológica. Nota técnica conjunta da Secretaria de Vigilância em Saúde do Ministério da Saúde e da Secretaria de Estado da Saúde do Rio Grande do Sul sobre a situação da Leishmaniose Visceral na fronteira do estado do Rio Grande do Sul com a Argentina. Brasília, 2010. 3 p. Disponível em: <http://portal.saude. gov.br/portal/ arquivos/pdf/>. Acesso em: 6 maio 2016.

CALDART, E. T.; FREIRE, R. L.; FERREIRA, F. P.; RUFFOLO, B. B.; SBEGHEN, M. R.; MAREZE, M.; GARCIA, J. L.; MITSUKA-BREGANÓ, R.; NAVARRO, I. T. Leishmania in synanthropic rodents (Rattus rattus): new evidence for the urbanization of Leishmania (Leishmania) amazonensis. Revista Brasileira de Parasitologia Veterinária, Jaboticabal, v. 26, n. 1, p. 17-27, 2017.

D'ANDREA, L. A. Z.; SILVA FONSECA, E. da; PRESTES-CARNEIRO, L. E.; GUIMARÃES, R. B.; YAMASHITA, R. C.; SOARES, C. N.; HIRAMOTO, R. M.; TOLEZANO, J. E. The shadows of a ghost: a survey of canine leishmaniasis in Presidente Prudente and its spatial dispersion in the western region of São Paulo state, an emerging focus of visceral leishmaniasis in Brazil. BMC Veterinary Research, London, v. 11, n. 1, p. 273, 2015.Disponivel em: <https://bmcvetres. biomedcentral.com/articles/10.1186/s12917-015-05836>. Acesso em: 09 mar. 2017.

OLIVEIRA, T. M. F. de S.; FURUTA, P. I.; CARVALHO, D. de; MACHADO, R. Z. A study of cross-reactivity in serum samples from dogs positive for Leishmania sp., Babesia canis and Ehrlichia canis in enzyme-linked immunosorbent assay and indirect fluorescent antibody test. Revista Brasileira de Parasitologia Veterinaria, Jaboticabal, v. 17, n. 1, p. 7-11, 2009.

SANTOS, D. R. dos; FERREIRA, A. C. A. C.; BISETTO JUNIOR, A. The first record of Lutzomyia longipalpis (Lutz e Neiva, 1912) (Diptera: Psychodidae: Phlebotominae) in the State of Paraná, Brazil. Revista da Sociedade Brasileira de Medicina Tropical, Uberaba, v. 45, n. 5, p. 643-645, 2012.

SANTOS, S. O. dos; ARIAS, J.; RIBEIRO, A. A.; HOFFMANN, M. D. P.; FREITAS, R. A. D.; MALACCO, M. A. F. Incrimination of Lutzomyia cruzi as a vector of American Visceral Leishmaniasis. Medical and Veterinary Entomology, Medford, v. 12, n. 3, p. $315-$ 317, 1998.

SCHÖNIAN, G.; NASEREDDIN, A.; DINSE, N.; SCHWEYNOCH, C.; SCHALLIG, H. D. F. H.; PRESBER, W.; JAFFE, C. L. PCR diagnosis and characterization of Leishmania in local and imported clinical samples. Diagnostic Microbiology and Infectious Disease, Amsterdam, v. 47, n. 1, p. 349-358, 2003.

SZARGIKI, R.; CASTRO, E. A. de; LUZ, E.; KOWALTHUK, W.; MACHADO, Â. M.; THOMAZSOCCOL, V. Comparison of serological and parasitological methods for cutaneous leishmaniasis diagnosis in the state of Paraná, Brazil. Brazilian Journal of Infectious Diseases, São Paulo, v. 13, n. 1, p. 47-52, 2009.

THOMAZ-SOCCOL, V.; CASTRO, E. A.; NAVARRO, I. T.; RODRIGUES DE FARIAS, M.; MARIA DE SOUZA, L.; CARVALHO, Y.; BISPO, N. S.; MEMBRIVE, A.; MINOZZO, J. C.; TRUPPEL, J.; BUENO, W.; LUZ, E. Casos alóctones de leishmaniose visceral canina no Paraná, Brasil: implicações epidemiológicas. Revista Brasileira de Parasitologia Veterinária, Jaboticabal, v. 18, n. 3, p. 46-51, 2009.

WENZEI, K. Santa Catarina tem primeiro caso de Leishmaniose visceral humana. Jornal de Santa Catarina, Florianópolis, 17, ago. 2017. Notícias. Disponível em: <http://jornaldesantacatarina.clicrbs. com.br/sc/noticia/ 2017/08/santa-catarina-tem-primeirocaso-deleishmaniose-visceral-humana-9872502.html>. Acesso em: 4 set. 2017. 
